Article

\title{
Preliminary Study on the Control of Cucumber Green Mottle Mosaic Virus in Commercial Greenhouses Using Agricultural Disinfectants and Resistant Cucumber Varieties
}

\author{
Walid Ellouze ${ }^{1,2, *(D)}$, Vachaspati Mishra ${ }^{1}$, Ronald J. Howard ${ }^{3}$, Kai-Shu Ling ${ }^{4}$ \\ and Weizheng Zhang ${ }^{1}$ \\ 1 Alberta Agriculture and Forestry, Greenhouse Section, Crop Diversification Centre South, 301 Horticultural \\ Station Rd. E., Brooks, AB T1R 1E6, Canada; mishravachaspati31@gmail.com (V.M.); \\ wzhang1234@yahoo.com (W.Z.) \\ 2 Agriculture and Agri-Food Canada, 4902 Victoria Avenue North, Vineland Station, ON L0R 2E0, Canada \\ 3 RJH Ag Research Solutions Ltd., Box 1456, Brooks, ABvT1R 1C3, Canada; agresearch@eidnet.org \\ 4 USDA-Agricultural Research Service, U.S. Vegetable Laboratory, 2700 Savannah Highway, \\ Charleston, SC 29414, USA; kai.ling@usda.gov \\ * Correspondence: oualid.ellouz@canada.ca
}

Received: 16 October 2020; Accepted: 24 November 2020; Published: 27 November 2020

\begin{abstract}
Cucumber green mottle mosaic virus (CGMMV) is a re-emerging threat to greenhouse cucumber and other Cucurbitaceae crop production worldwide. This seed-borne virus can easily spread from a contaminated seeds to seedlings and to adjacent plants through mechanical contact of the foliage of diseased and healthy plants causing extensive yield losses. Additionally, infection may not be limited to the current crop but may also affect subsequent crops due to the long-term persistence of the virus on contaminated crop residues, greenhouse hard surfaces and soil or soil-less greenhouse substrates. In the present work, three greenhouse experiments were conducted to develop an integrated pest management strategy towards controlling CGMMV in commercial cucumber greenhouses, by implementing an effective sanitization program and using resistant and grafted cucumber varieties. Results of sanitization highlighted that pressure washing and cleansing with an alkaline foam cleanser eliminated CGMMV on some of the most heavily infested areas. However, three successive applications of cleanser and disinfectants were essential to completely eliminate CGMMV on porous and uneven surfaces, such as cement alleyway, tray gutters and floor mats. The screening of 15 cucumber varieties revealed that one Mini ('Khassib') and three Long English ('Sepire', 'Bomber' and 'LC13900') had reduced or delayed CGMMV infection spread in the greenhouse but were intermediate in yield. The most resistant Mini variety was 'Katrina'. This variety showed low CGMMV infection level and high fruit yield. The varieties 'Jawell', 'RZ 22-551', 'Sunniwell', 'Bonbon' and 'Dee Lite' were the most tolerant to CGMMV. They showed a high CGMMV infection level without compromising yield. These results proved the need for new productive cucumber varieties with CGMMV resistance. Grafting experiments showed a yield increase only in the case of grafted 'Picowell' over 'Bonbon' but no CGMMV resistance, which is a much more desirable result of grafting experiments in order to have economic potential. In all, the current study revealed unique methods of CGMMV management in commercial greenhouses that are recommended to growers for reducing crop losses and improving economic returns.
\end{abstract}

Keywords: Cucumis sativus L.; Tobamovirus; greenhouse sanitization; biosecurity; disease resistance; grafting 


\section{Introduction}

Cucumber green mottle mosaic virus (CGMMV), a member of the genus Tobamovirus in the family Virgaviridae, is an increasing threat to cucumber (Cucumis sativus L.) and other Cucurbitaceae crop production globally [1,2]. This re-emerging virus can cause extensive damage to cucumber crops resulting in substantial yield losses and a lower market value [1,3]. This seed-borne virus can easily spread across short and long distances through the use of contaminated seeds and infected seedlings [4-6]. CGMMV was first described in 1935 in the United Kingdom [7], and eventually it spread worldwide to almost all cucurbit-producing regions [1,8-19]. CGMMV can infect a number of common weed species in the families Euphorbiaceae, Solanaceae, Lamiaceae, Boraginaceae, Apiaceae, Amaranthaceae, Chenopodiaceae and Portulacaceae, which in turn may serve as virus reservoirs $[1,20,21]$.

Although the level of natural virus transmission through seed is relatively low [22], the ease of mechanical transmission of CGMMV especially in propagation houses, makes this virus very contagious [6]. The mechanical transmission of the virus may occur by various means, including the handling of plants, leaf contact, wounds made with cutting tools, farm equipments [4], chewing insects such as the cucumber leaf beetle (Raphidopalpa fevicollis) [23], and pollinators such as European honeybees (Apis mellifera L.) [24]. A single CGMMV-infected plant in a cucumber greenhouse may result in the infection of entire crop. In addition, the virus is extremely stable and its particles may remain viable for several months in crop residues, soil and on greenhouse hard surfaces under relatively extreme climatic conditions [11]. The high stability of CGMMV combined with its high infectivity rate through mechanical transmission and capacity to affect subsequent greenhouse crops, have increased the economic importance of this virus. High CGMMV infections may force growers to terminate their crops early because of unproductiveness, hence reducing the overall profitability of their operations $[3,25]$.

To date, no effective chemical or cultural control methods have been developed to prevent CGMMV spread. Multiple approaches should be developed and adopted to prevent the introduction and delay the spread of the virus in commercial cucumber greenhouses. Using an integrated pest management (IPM) approach will minimize the negative effects of CGMMV on cucumber production and keep the disease damage under the economic threshold. CGMMV disease management must include removal of virus reservoirs, phytosanitary practices, the use of certified virus-free seeds, selection of a resistant cultivars, and the use of grafted plants [26].

Greenhouse sanitization, which consists of cleaning and disinfection, is the cornerstone of an effective greenhouse IPM/Biosecurity program. It is an effective process of decontaminating surfaces that may have become contaminated with pathogens, insects, mites, nematodes, weeds, algae, etc. An effective sanitization program should lead to the reduction or elimination of active and dormant stages of pathogens and pests, as well as to disrupt their life cycle. Cleaning a commercial greenhouse facility after infection of a cucumber crop with CGMMV is a difficult task and requires patience and attention to detail because the virus is persistent on substrate bags, walkways, bench tops, troughs, small equipment, produce baskets, workers' clothing and hands, and on many other surfaces within production facilities. Therefore, understanding where the virus can be found in a commercial greenhouse and how persistent it is in the environment is a key step in developing an effective sanitization program. Effective sanitization strategies for this virus are mainly aimed at reducing or eliminating existing sources of infection and the prevention of virus transmission.

Host resistance is one of the most desirable viral disease management strategies and some commercially available greenhouse cucumber cultivars are described by the seed companies as having high or intermediate resistance to CGMMV (Table 1). However, there is limited knowledge regarding the genetic mechanisms involved in resistance to CGMMV in cucumbers and other cucurbits. Two partially resistant $C$. sativus accessions were identified with mild CGMMV disease symptoms [27]. Although, no commercially available greenhouse cucumber varieties are immune to CGMMV, a better understanding of their relative resistance and susceptibility to the Canadian isolate of CGMMV would be beneficial. Science- based recommendations need to be available to greenhouse cucumber growers, 
including the opportunity to select the most disease resistant/tolerant and agronomically suitable varieties for CGMMV management in commercial greenhouses.

Table 1. List of Mini and Long English cucumber varieties evaluated in trial and their level of resistance to different diseases according to the seed companies.

\begin{tabular}{|c|c|c|c|c|}
\hline Cucumber Type & Seed Company & $\begin{array}{l}\text { Variety Name and } \\
\text { (\#) }\end{array}$ & High Resistance & Intermediate Resistance \\
\hline \multirow{6}{*}{ Mini } & \multirow{4}{*}{ Rijk Zwaan } & Sunniwell (1) & Ccu & CGMMV/CMV/CVYV/Px \\
\hline & & Deltastar (2) & $\mathrm{Cca} / \mathrm{Ccu} / \mathrm{Px}$ & CMV/CVYV \\
\hline & & RZ 22-551 (3) & CGMMV & - \\
\hline & & Khassib (4) & $\mathrm{Ccu} / \mathrm{Px}$ & CMV/CVYV/PRSV/WMV/ZYMV \\
\hline & $\begin{array}{l}\text { Monsanto/De } \\
\text { Ruiter }\end{array}$ & Jawell (5) & - & $\mathrm{CMV} / \mathrm{CVYV} / \mathrm{Px}$ \\
\hline & Enza Zaden & Katrina (6) & Ccu & $\mathrm{Px} / \mathrm{CMV} / \mathrm{CVYV}$ \\
\hline \multirow{9}{*}{ Long English } & $\begin{array}{l}\text { Monsanto/De } \\
\text { Ruiter }\end{array}$ & DR4879CE (7) & Px & CGMMV \\
\hline & \multirow{2}{*}{ Syngenta } & Bomber (8) & $\mathrm{Px}$ & CGMMV/CMV \\
\hline & & LC13900 (9) & CGMMV & - \\
\hline & \multirow{2}{*}{ Enza Zaden } & Dee Lite (10) & Ccu & CGMMV/CMV/CVYV/Px \\
\hline & & Komet (11) & $\mathrm{Cca} / \mathrm{Ccu}$ & CGMMV/CMV/CVYV/Px \\
\hline & \multirow{3}{*}{ Rijk Zwaan } & Bonbon (12) & CGMMV/Ccu & CVYV/Px \\
\hline & & Verdon (13) & CGMMV/Cca/Ccu/Px & $\mathrm{CMV} / \mathrm{CVYV}$ \\
\hline & & Addison (14) & $\mathrm{Ccu} / \mathrm{Px}$ & CGMMV/CMV/CVYV \\
\hline & Nunhems & Sepire (15) & CGMMV & - \\
\hline
\end{tabular}

Cca-Corynespora leaf spot caused by Corynespora cassiicola; $\mathrm{Ccu}-\mathrm{Scab}$ and gummosis caused by Cladosporium cucumerinum; CVYV-Cucumber vein yellowing virus; CGMMV-Cucumber green mottle mosaic virus; Px—Powdery mildew caused by Podosphaera xanthii; WMV—Watermelon mosaic virus; PRSV—Papaya ringspot virus; ZYMV—Zucchini yellow mosaic virus; CMV—Cucumber mosaic virus.

While breeding for viral disease resistance is a long-term process, vegetable grafting offers a short term alternative for compiling tolerance traits and improving yield potential [28,29]. Grafted plants have greater tolerance to biotic and abiotic stresses thus providing higher fruit yields [30,31]. The enhanced tolerance in grafted plants has been attributed to increases in vigor, improved photosynthetic efficiency, stronger antioxidative defense system, heightened hormonal signaling and long-distance movement of mRNAs, small RNAs and proteins [29,32]. Grafting on resistant rootstocks has been reported to confer resistance in cucumber to foliar fungal pathogens, such as target leaf spot, powdery mildew and downy mildew [33-37]. Tolerance to viruses in seedless watermelon plants was reported to be improved by grafting [38]. Pepino mosaic virus, Tomato yellow leaf curl virus and Tomato spotted wilt virus were also reported to be controlled by grafting [30]. In hydroponic production systems, roots of a disease-resistant rootstocks provide an extra line of defense against pathogens in potentially contaminated recirculating nutrient solution. Currently, knowledge about CGMMV resistant rootstocks is limited, and information on the usage of plants grafted onto resistant rootstocks in commercial greenhouses is not available.

The objective of our study was to develop a management strategy towards controlling CGMMV in commercial cucumber greenhouses by implementing an effective sanitization program and using virus-resistant and grafted cucumber varieties to effectively manage CGMMV disease without compromising overall crop production and impacting its economic value.

\section{Materials and Methods}

\subsection{Evaluation of the Effectiveness of Different Sanitization Steps}

An extensive environmental sampling of hard surfaces in a 15-acre commercial cucumber greenhouse with a high incidence of CGMMV disease ( $>50 \%$ infected plants) in Alberta, Canada was performed before and after each sanitization step (Figure 1). Before crop removal, three of the 
most infected greenhouse areas ( $>90 \%$ infected plants) were identified. Solar-Cult ${ }^{\circledR}$ Pre-moistened Sampling Cellulose Sponge Kit (www.solarbiologicals.com) was used for sampling from 15 different hard surfaces in each of the three infected areas including cement alleyways, tray gutters, rail brackets, rails, floor fabrics, water hoses below trays, tray end irrigation/drain hoses, canopy heating pipes, tray tops, support posts, steel beam tray supports, cropping wires, perimeter heating pipes, interior walls, and shade curtains on walls. Samples were also collected post-crop removal, post pressure washing, after cleaning with an alkaline foam cleaner (MS Topfoam LC ALK, Schippers Canada Ltd., Lacombe County, AB, Canada), and after application of alkaline (C-Clean, Leamington, ON, Canada) and peroxide surface disinfectants (Virkon ${ }^{\circledR}$ Greenhouse, Vétoquinol N.-A. Inc., Lavaltrie, QC, Canada), according to the manufacturer's instructions (Figure 1).

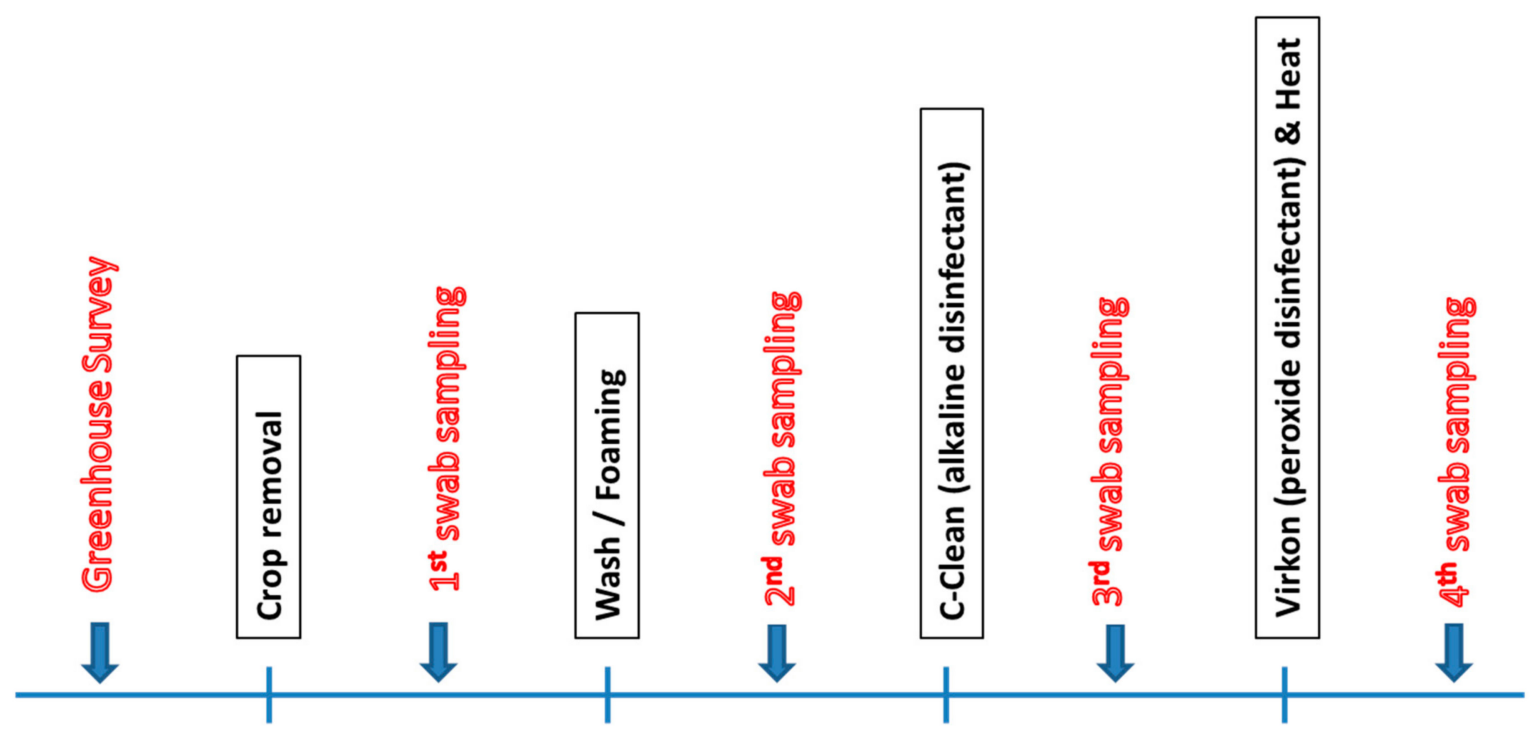

Figure 1. Flow chart of environmental sampling steps in a commercial greenhouse for evaluating the effectiveness of eliminating cucumber green mottle mosaic virus using different sanitization procedures.

Sample Processing, ELISA and in Planta Virus Bioassay

To facilitate extraction of liquid buffer containing the surface contaminants from the pre-moistened sampling cellulose sponges, the samples were diluted with $5 \mathrm{~mL}$ of sterile distilled water followed by homogenization in a Stomacher Lab Blender 400 (AJ Seward, Edmunds, UK) for $2 \mathrm{~min}$. A $4.5 \mathrm{~mL}$ of the extract was used in a bioassay to confirm the presence and infectivity of the virus as described below. The remaining portion of the sample was analyzed for CGMMV particles using the CGMMV-ELISA kit (Agdia Inc., Elkhart, IN, USA) according to the manufacturer's instructions. ELISA plates were read at $\mathrm{OD}_{405} \mathrm{~nm}$ with a 'Synergy HT' microplate reader using 'GEN5 ${ }^{\mathrm{TM}}$ ' software version 2.04. (Bio Tek ${ }^{\circledR}$ Instruments Inc., Winooski, VT, USA). Negative (liquid buffer from the Solar-Cult ${ }^{\circledR}$ Pre-moistened Sampling Cellulose Sponge Kit) and positive (crude extracts from cucumber leaves infected with CGMMV) controls were run in triplicate on each plate. A sample was considered CGMMV-infected if its $\mathrm{OD}_{405 \mathrm{~nm}}$ absorbance value plus standard error was at least two times greater than the negative control.

To confirm the presence and infectivity of the virus, an in planta bioassay was conducted by mechanically inoculating three susceptible mini cucumber seedlings of the variety 'Picowell' at the four true-leaf stage with the extract from each cellulose sponge. Mechanical inoculation was performed by rubbing the surface of the leaf using a brush soaked with inoculum in a way to break the surface cells without causing too much leaf damage. Negative controls are non-inoculated plants and the positive control was inoculated with CGMMV. CGMMV-infected plants displayed symptoms at 18 days post-inoculation (dpi). Symptomatic and asymptomatic cucumber plants were tested $40 \mathrm{dpi}$ to confirm the presence or absence of CGMMV using the CGMMV ImmunoStrip ${ }^{\circledR}$ test kit (Agdia, Inc., Elkhart, IN, USA) according to the manufacturer's instructions. 


\subsection{Evaluation of Commercial Cucumber Varieties for Their Resistance to CGMMV and Yield Potential}

Six Mini and nine Long English (LE) cucumber varieties with different levels of resistance to CGMMV (based on the seed companies data) and other pathogens (Table 1), which used by commercial cucumber growers, were screened for their potential resistance to CGMMV and the effects of infection on cucumber plant productivity. Only certified healthy cucumber seeds and seedlings were used in this experiment. Seeds were germinated in rockwool cubes (Cultilene Pc, Saint-Gobain, Rijen, The Netherlands) placed on flood tables in a propagation house. Rockwool cubes were soaked in water or nutrient solution for $5 \mathrm{~min}$ daily. Seedlings were grown at day/night temperatures of $25 / 20 \pm 2{ }^{\circ} \mathrm{C}$ and $16 \mathrm{~h}$ photoperiod for $15 \mathrm{~d}$ prior to transplanting. Cucumber plants were transplanted at the four-leaf stage and cultivated under optimal commercial fertilization and environment conditions for $12 \mathrm{wk}$ during the 2015 summer season. The experiment was conducted in one multi-span $750 \mathrm{~m}^{2}$ glass greenhouse compartment in the Greenhouse Research and Production Complex at the Crop Diversification Centre South, Brooks, Alberta. Coconut Coir Growbags (Millenniumsoils Coir ${ }^{\mathrm{TM}}$, St. Catharines, ON, Canada) were used to support hydroponic production of high-wire cucumber crops on raised-troughs. All the treatments were arranged in a randomized complete block design with three replicates of each of the treatments. Each treatment contained 24 cucumber plants planted in four coconut coir growbags and organized in one row. This resulted in a plant density of 3.2 plants/sq $\mathrm{m}$. The nutrient solution of same standard composition was supplied to cucumber plants via a fertigation system using irrigation drippers. Plants received $2 \mathrm{~L} / \mathrm{h}$ of nutrient solution containing $200 \mathrm{ppm} \mathrm{N}$, 55 ppm P, 350 ppm K, 220 ppm Ca, 135 ppm S, 75 ppm Mg, 4 ppm Fe, 0.8 ppm Mn, 0.6 ppm B, 0.2 ppm $\mathrm{Cu}, 0.4 \mathrm{ppm} \mathrm{Zn}$ and $0.17 \mathrm{ppm}$ Mo. The electrical conductivity (EC) of the nutrient solution was $2 \pm 0.2 \mathrm{dS} / \mathrm{m}$. Irrigation management and climate set points, such as temperature (day/night 23/18 \pm $\left.2{ }^{\circ} \mathrm{C}\right)$, light $(20 \mathrm{~h}$ photoperiod $), \mathrm{CO}_{2}(900 \mu \mathrm{mol} / \mathrm{mol})$ and relative humidity $(0.5 \mathrm{KPa}$ Vapor Pressure Deficit) were controlled through an automated Argus computer control system (Argus Control Systems Limited, Surrey, BC, Canada).

The crop was monitored for insects, mites and diseases during the season using standard integrated pest management (IPM) scouting techniques. Two Floramite ${ }^{\circledR}$ SC (bifenazate $22.6 \%$ SU) (Chemtura Canada Co./Cie, Elmira, ON, Canada), two Dibrom ${ }^{\circledR}$ (naled 900g/L EC) (Loveland Products Canada Inc., Dorchester, ON, Canada) and one Kopa Insecticidal Soap (potassium salts of fatty acids $47.0 \% \mathrm{SN}$ ) (Neudorff North America, Saanichton, BC, Canada) spray applications were required during the crop trial for the control of spider mites.

\subsubsection{Inoculum Collection and Maintenance}

The CGMMV strain used as inoculum in this study was isolated from a diseased cucumber plant collected in a commercial greenhouse in Alberta, Canada and maintained through rub-inoculation on the susceptible mini cucumber variety 'Picowell' in a growth chamber. The complete genome sequencing of this CGMMV isolate (GenBank accession no. KP772568) revealed that it was closely related to isolates of Asian origin ( $98 \%$ to $99 \%$ nucleotide sequence identities) [39].

\subsubsection{Monitoring the Presence and Spreading Pattern of CGMMV in a Greenhouse}

The primary source of infection was introduced to the greenhouse through the inoculation of first plant of each row with a local CGMMV strain, $7 \mathrm{~d}$ after transplanting (4 true-leaf stage) by rub-inoculation, as described above (Supplementary Materials Figure S1). The secondary spread of the virus to neighboring plants occurred mechanically through plant handling, leaf contact, wounds made by cutting tools, or farming equipment. Cucumber plants were twisted, clipped, de-leafed and lowered twice/wk and fruits were harvested thrice/wk. Before moving from one plot to the next, new gloves were worn and the cutting tools and farming equipment were disinfected using $2 \%$ Virkon (potassium peroxymonosulphate $21.4 \% \mathrm{SP}$ ). 
In order to measure the disease incidence, all cucumber plants were visually examined weekly for the appearance of CGMMV symptoms, starting one-week post-inoculation. Symptomatic and asymptomatic cucumber plants were tested to confirm the presence or absence of CGMMV using the ImmunoStrip ${ }^{\circledR}$ test kit.

\subsubsection{Data Collection and Statistical Analyses}

Disease incidence was recorded weekly. Area under disease progress curve (AUDPC) was calculated for each plot according to Simko and Piepho [40] as follows:

$$
A U D P C=\sum_{i=1}^{n-1}\left(\frac{Y i+1+Y i}{2}\right)(t i+1-t i)
$$

where $Y_{i}=$ the proportion of diseased cucumber plants at $i$ th observation, $t_{i}=$ time of the $i$ th observation in days from the first observation and $n=$ total number of disease observations. AUDPC was used to assess quantitative disease resistance in cucumber varieties [41].

Cucumber fruits were harvested thrice/wk and the number of fruit and fruit weight/plot were recorded. The data was subjected to ANOVA using JMP ${ }^{\circledR}$ 15.0.0 (SAS Institute Inc., Cary, NC, USA) and, in the presence of treatment effects, the statistical significance of differences between treatment means was assessed using the Least Significant Difference (LSD) test.

\subsection{Evaluation of Grafted Cucumber Plants for Resistance to CGMMV and Yield Potential}

Grafted plants consisted of scion and rootstock of the CGMMV susceptible Mini cucumber variety 'Picowell' and the CGMMV highly resistant (seed company data) LE cucumber variety 'Bonbon', respectively. Certified healthy cucumber seeds were germinated in Cultilene Pc rockwool cubes placed on flood tables in a propagation house. Rockwool cubes were soaked in water or nutrient solution for $5 \mathrm{~min}$ daily. Seedlings were grown at $25 / 20 \pm 2{ }^{\circ} \mathrm{C}$ day/night and $16 \mathrm{~h}$ photoperiod for $5 \mathrm{~d}$ before grafting or transplanting for non-grafted plants. Grafting was conducted at one cotyledon stage when cotyledons of scions and rootstocks were completely unfolded [42]. The grafted seedlings were then placed in a greenhouse mist chamber, where a fine water mist was delivering every $10 \mathrm{secs} / \mathrm{min}$. Seedlings were kept in the mist chamber for $3 \mathrm{~d}$, then transferred to flood tables in propagation house and grown for an additional week prior to transplanting into a poly greenhouse compartment. Grafted and non-grafted cucumber plants were transplanted at the four-leaf stage and cultivated under optimal commercial fertilization and environmental conditions, as described above, for $12 \mathrm{wk}$ during the fall season. Coconut coir growbags were used to support hydroponic production of the cucumber crop maintained in an umbrella system. All of the treatments were arranged in a randomized complete block design with six replicates for each treatment. Each treatment contained one cucumber plant planted in a coconut coir growbag. Plants were either inoculated with CGMMV or sterile water (negative control) $7 \mathrm{~d}$ after transplanting by rub-inoculation. Weekly fruit yield and internode number were recorded. The data were subjected to ANOVA using JMP ${ }^{\circledR}$ 15.0.0 (SAS Institute Inc., Cary, NC, USA) and, in the presence of treatment effects, the significance of differences between treatment means was assessed using the Least significant difference (LSD) test.

\section{Results}

\subsection{Evaluation of the Effectiveness of Different Sanitization Steps Performed in a Commercial Greenhouse}

There was a high variability of CGMMV frequency on all tested surfaces (Table 2). After crop removal, the majority of surface sample tested positive for CGMMV, with the exception of interior walls, perimeter heating pipes, wall-shade curtains and crop support wires. Surfaces directly in contact with plants were the most heavily infested areas, with tray tops $(0.303 \pm 0.019)$ and tray gutters $(0.308 \pm 0.035)$ having the highest levels of CGMMV. Additional areas with high levels of CGMMV included rails $(0.259 \pm 0.033)$, rail brackets $(0.296 \pm 0.045)$, water hoses below trays $(0.231 \pm 0.020)$ and 
cement alleyway $(0.292 \pm 0.039)$. Cleaning using pressure washing and MS TopFoam reduced detectable levels of CGMMV in all treatments. However, tray tops, rails and rails brackets surfaces were easier to clean than cement alleyway, tray gutter and floor mats (Table 2). Cleaning using MS TopFoam LC Fresh cleaner (sodium hydroxide 7\%, 2-(2-butoxyethoxy) ethanol 7\%, tetrasodium EDTA 6\%, sodium laurel sulphate $5 \%$, was sufficient to eliminate CGMMV on all infested surfaces, except tray gutters, cement alleyways and floor mats. Two sanitization steps by MS TopFoam and C-Clean (chlorinated alkaline cleaner) were necessary to eliminate CGMMV from tray gutters and floor mats. Cement alleyway was the most difficult surface to disinfect and all cleaning/disinfecting steps, including the use of Virkon (peroxide disinfectant) and heat, were needed to eliminate CGMMV infectivity.

Table 2. Assessment of residual Cucumber green mottle mosaic virus (CGMMV) using enzyme-linked immunosorbent assay (ELISA) on various surfaces after different cleaning and sanitization procedures in a commercial greenhouse.

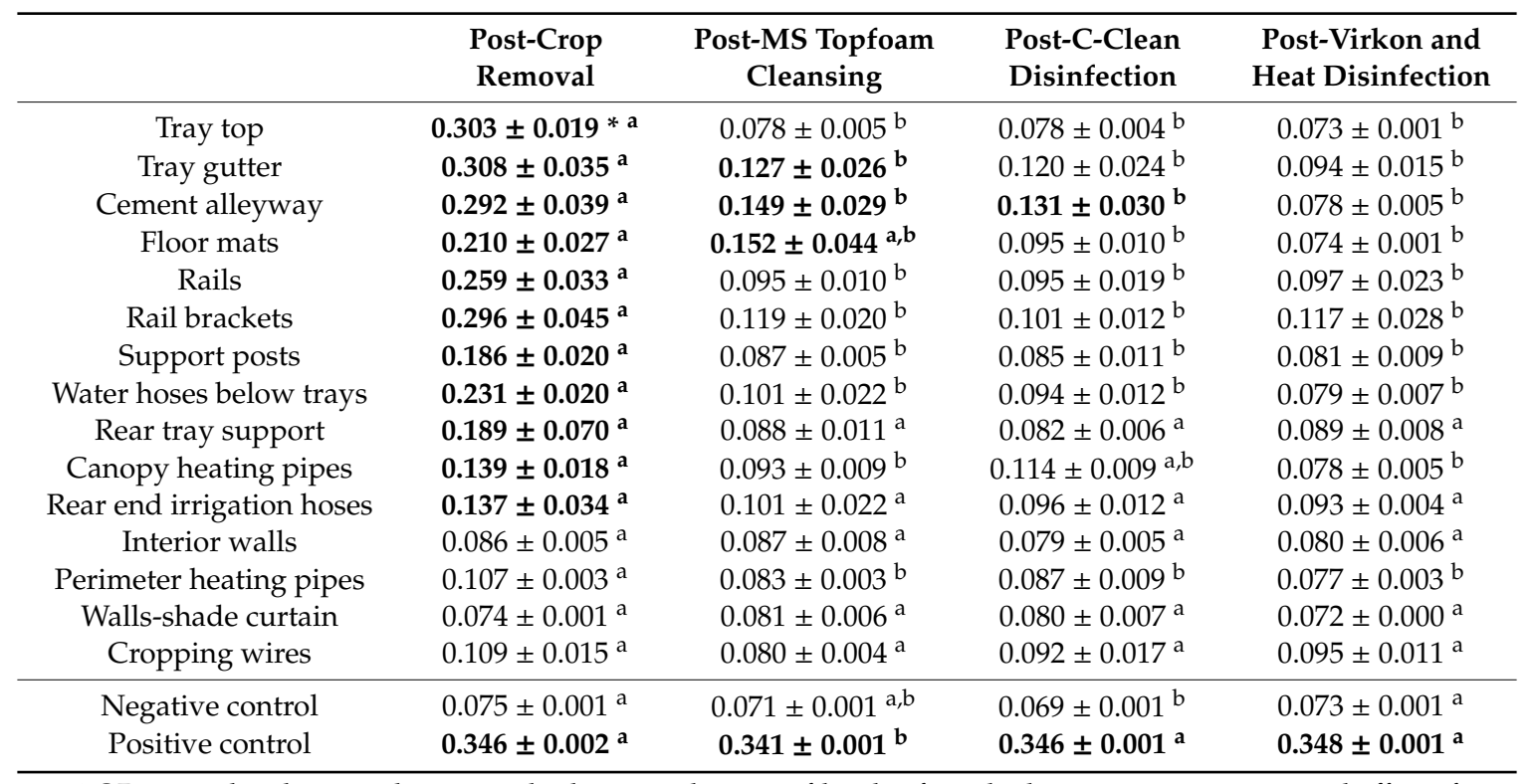

* $\mathrm{OD}_{405 \mathrm{~nm}}$ absorbance value \pm standard error indicative of levels of residual virus contamination and effect of different cleaning/disinfecting steps on 15 different hard surfaces in a commercial cucumber greenhouse. Samples with $\mathrm{OD}_{405 \mathrm{~nm}}$ absorbance values in bold were considered to be CGMMV infected (positive). Virus infectivity was confirmed in a greenhouse bioassay where three mini cucumber seedlings were inoculated for each treatment and if one of the three seedlings show CGMMV symptoms, the treatment was considered as positive. Least square means are not significantly different according to ANOVA LSMeans Student's $t$ tests when followed by the same letter on the same row $(\alpha=0.05, n=3)$.

\subsection{Spread Pattern of CGMMV Infection in a Greenhouse}

Overall, CGMMV rapidly spread in mini cultivars of cucumbers compared to Long English (LE) cultivars (Figure 2). In mini cultivars, CGMMV symptoms first appeared at $10 \mathrm{dpi}$, and there was an exponential spread of virus in new plants with symptoms after 25 dpi (Figure 2). CGMMV symptom development in LE cucumbers was first observed at $10 \mathrm{dpi}$, similar to mini cultivars. However, spread of CGMMV to new plants was greatly slower in LE cultivars as exponential spread of the virus only occurred after 52 dpi (Figure 2). Moreover, the mini cultivars showed almost 100\% infection by the end of crop production cycle, except for the 'Katrina' variety which reached a maximum level of $80 \%$ infected plants. CGMMV infection of LE cultivars was much lower within the same time period ranging between $45 \%$ and $90 \%$ infected plants. Within LE varieties, the 'DR4879CE' had the highest infection rate (90.28\%), while 'LC13900', 'Bomber' and 'Sepire' all had infection levels at near 50\% at the end of the crop production cycle (Figure 2). 

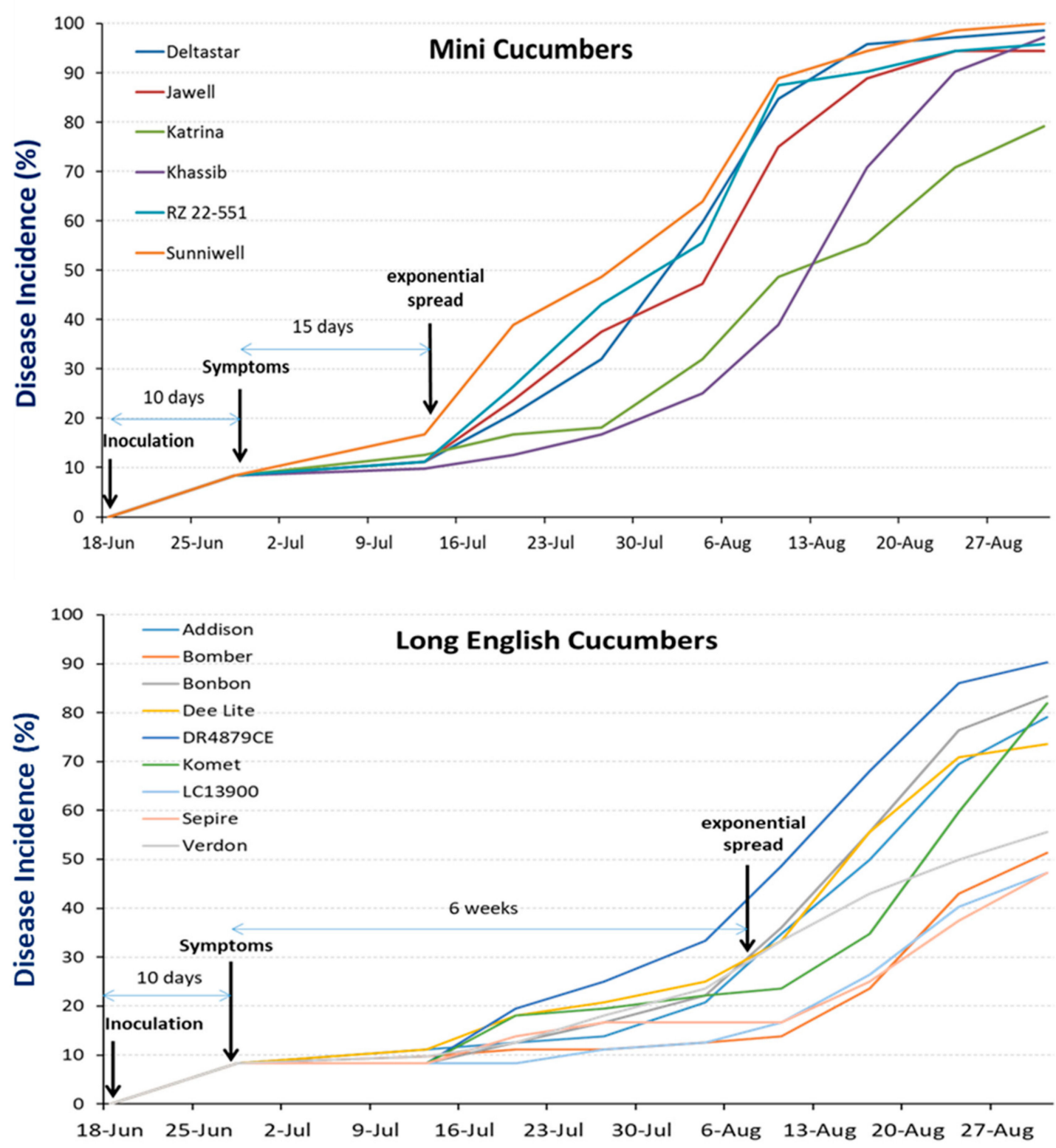

Figure 2. Disease progression curves of Cucumber green mottle mosaic virus as measured on various varieties of Mini and Long English cucumbers in a crop production season.

3.3. Levels of Resistance to CGMMV in Greenhouse Cucumber Varieties and Effects of Infection on Their Productivity

Among six Mini varieties, 'Jawell', 'RZ 22-551' and 'Sunniwell' were the most tolerant to CGMMV. These varieties showed high CGMMV infection level, however, they had the highest fruit yield. 'Katrina' and 'Khassib' were the most resistant, but 'Khassib' was intermediate in yield compared to 'Jawell', 'Katrina', 'RZ 22-551' and 'Sunniwell'. The most susceptible Mini variety was 'Deltastar'. This variety showed high CGMMV infection level and low fruit yield (Figure 3).

Among nine varieties of LE screened for resistance to CGMMV, 'Bonbon' was tolerant. This variety showed a high CGMMV infection level (AUDPC $=1980.56 \pm 117.98)$ without compromising yield, which was the highest among all varieties $\left(67.42 \pm 1.80 \mathrm{fruit} / \mathrm{m}^{2}\right)$ (Figure 3). The most susceptible LE variety was 'DR4879CE' (AUDPC $=2430.56 \pm 389.50$ ), while 'Verdon', the most widely grown cultivar in Alberta, showed intermediate (AUDPC $=1629.17 \pm 183.07$ ) resistance (Figure 3). In yield comparisons, 'DR4879CE' and 'Verdon' were poor performers (Figure 3). 

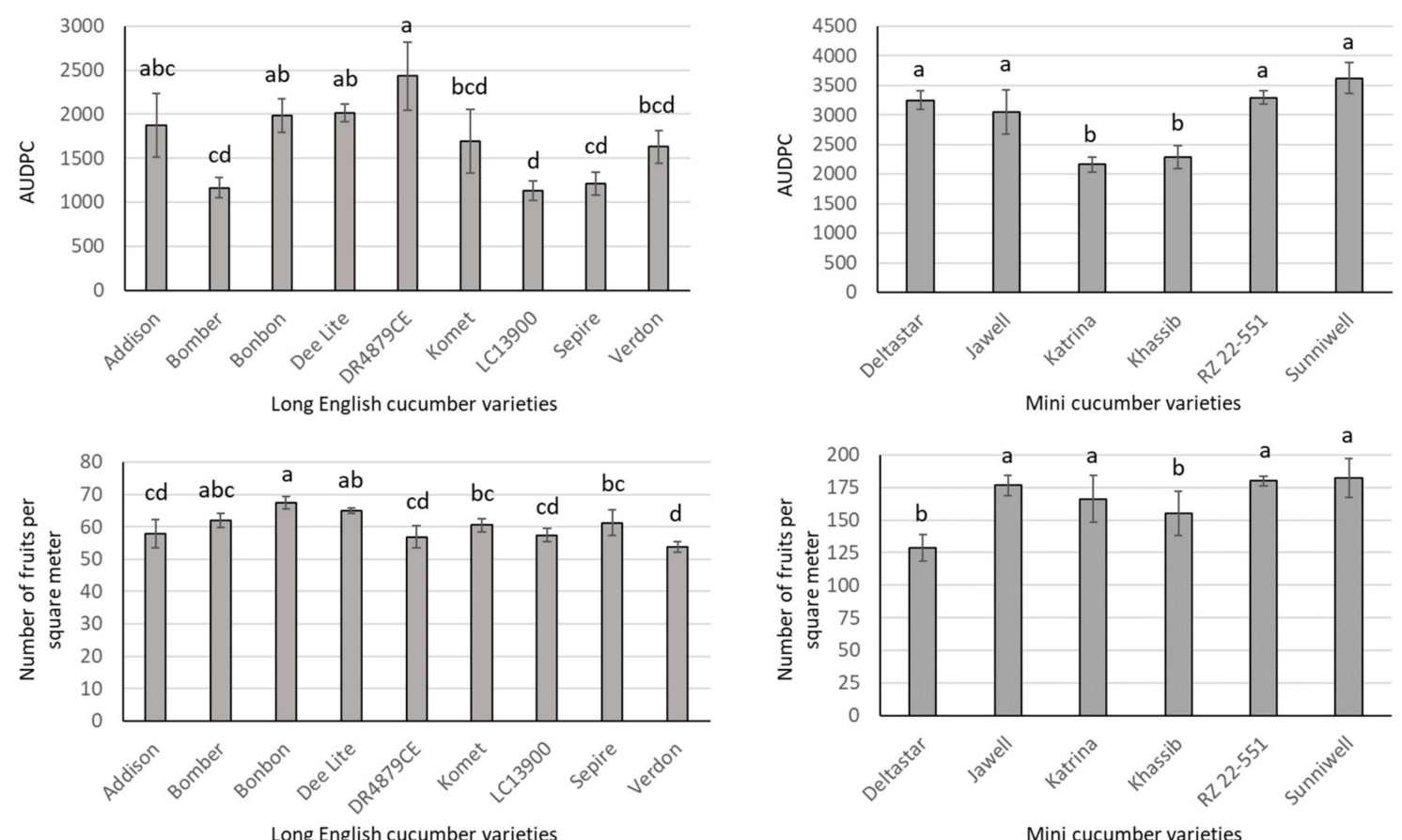

Figure 3. Quantitative disease resistance measured as area under disease progression curve (AUDPC) and yield in Mini and Long English greenhouse cucumber varieties infected by Cucumber green mottle mosaic virus. Bars represent least square means that are significantly different when associated with different letters, according to ANOVA LSMeans Student's $t$ tests $(\alpha=0.05)$. Error bars indicates standard error from three repeats $(n=3)$.

\subsection{Evaluation of Grafted Cucumber Plants for Resistance to CGMMV and Yield Potential}

In grafting experiments, CGMMV susceptible Mini cucumber variety 'Picowell' was used as the scion and LE cucumber variety 'Bonbon', described by the supplier as highly resistant to CGMMV, was chosen as the rootstock. The grafted plant was compared with the non-grafted counterparts for resistance to CGMMV and yield assessment. The grafted 'Picowell' on 'Bonbon' yielded $16 \%$ more than the non-grafted 'Picowell' (Figure 4). However, by using CGMMV infected grafts the yield of grafted plants was reduced (approximately $72 \%$ ) compared to non-infected grafted cucumbers. Similar results were obtained in the non-grafted cucumbers (Figure 4). The non-grafted 'Picowell' produced the highest internode numbers and the tallest plants in both inoculated and control treatments (Figure 4). 

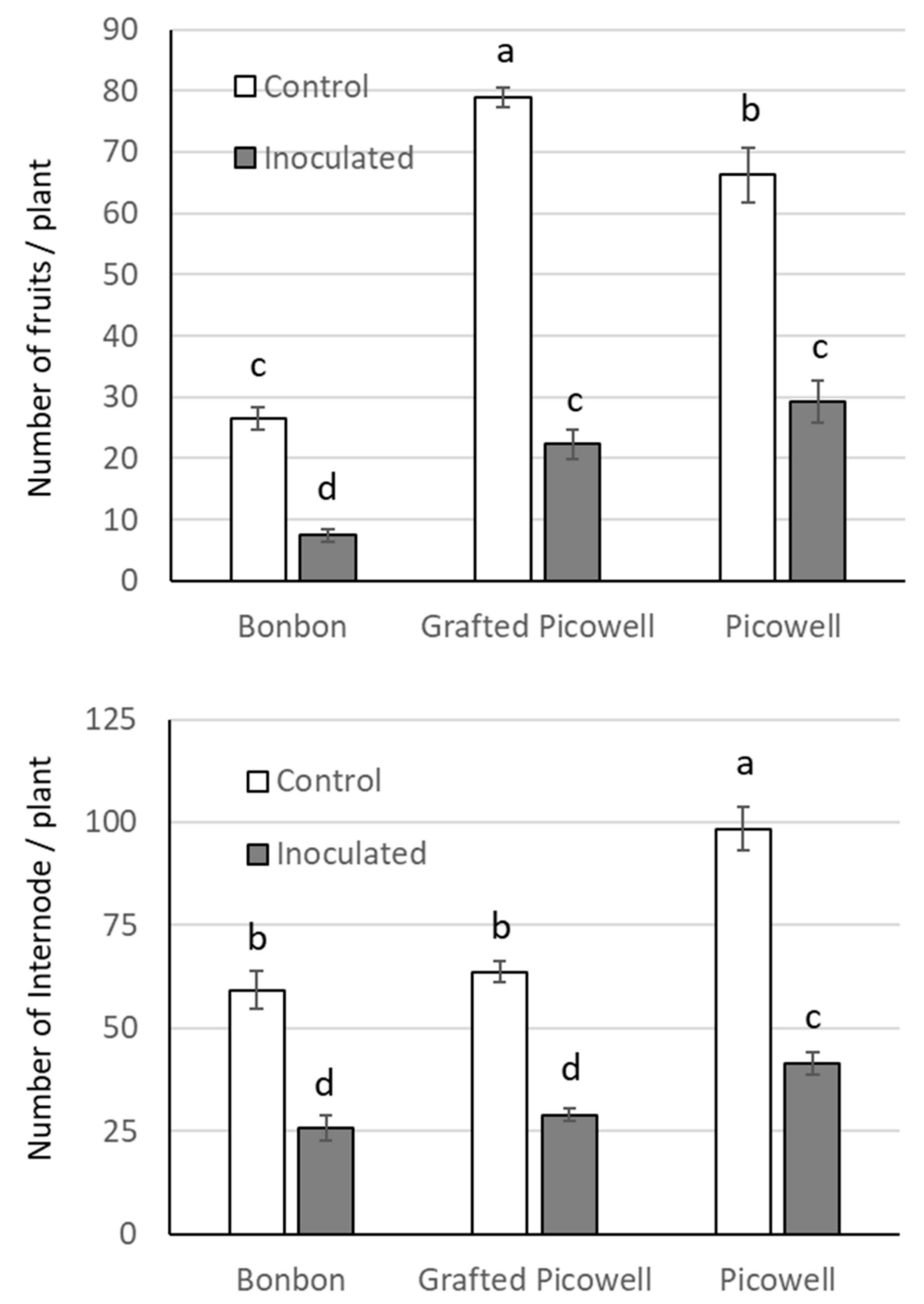

Figure 4. Effect of Cucumber green mottle mosaic virus infection on yield and internode number of grafted and non-grafted Mini and Long English greenhouse cucumber varieties. Bars represent least square means that are significantly different when associated with different letters, according to ANOVA LSMeans Student's $t$ tests $(\alpha=0.05)$. Error bars indicates standard error from six repeats $(n=$ $6)$.

\section{Discussion}

CGMMV is a serious threat to greenhouse cucumber, as well as to field cucurbit crop production worldwide. This virus is capable of rapidly spreading throughout a greenhouse or other protected cultivations, destroying crops and resulting in significant economic losses to growers [25]. CGMMV can also persist in environment, infect new crops and perpetuate the disease cycle. To our knowledge this is the first systematic analysis of the distribution of CGMMV within a commercial greenhouse, and the first study to evaluate different steps of decontamination approach of CGMMV in greenhouse cleaning.

Our results demonstrated the importance of using pressure washing and cleansing with an alkaline foam cleanser as a first step in sanitization procedure to significantly reduce or even eliminate CGMMV contamination of greenhouse surfaces. This step eliminated CGMMV on some of the most heavily infested areas and reduced detectable amounts of virus contamination on cement alleyways, 
tray gutters and floor mats. The critical importance of first step of sanitization lies in the fact that it was vitally important to remove the organic matter, as the primary source of disease-causing plant pathogens. This step should be carried out in advance of disinfection since some disinfectants are inactivated by direct contact with organic matter. The wide variation in antiviral activity of the same sanitizer on different surfaces could be explained by differences in surface porosities [43]. Our experimental data revealed that the third and fourth steps of sanitization, with alkaline and peroxide disinfectants, were essential to completely eliminate CGMMV on porous and uneven surfaces, such as cement alleyways, tray gutters and floor mats. These results corroborate previous findings suggesting that, in general, all disinfectants require higher concentrations and long exposure times to reduce significantly the microbial populations on porous surfaces [44]. Furthermore, it was found that two successive applications of disinfectant were more effective than a single, prolonged application in most instances due to a residual disinfectant activity remaining from the previous treatment [44]. These results are key in developing efficient methods for decontamination of commercial greenhouses infested with CGMMV.

The host resistance response to viral infection is often the most important aspect of control. Two Mini and three LE cucumber varieties, out of 15 evaluated varieties, had reduced or delayed CGMMV infection spread in the greenhouse. These varieties were similar to those cucumber cultivars reported by Čech and Branišová [45] with paradoxically severe symptoms and high resistance to virus reproduction. Cucumber plants from this group were inoculated with a stock virus suspension and many of them failed to become infected. The reduced spread of CGMMV may be associated with low viral titer due to low virus reproduction rate in these varieties. A recent study identified two partially resistant $C$. sativus accessions, out of 58 tested plants, using quantitative RT-PCR [27]. These accessions showed only mild CGMMV disease symptoms and low viral titer. Cucumber varieties with low virus replication capacity may be excellent candidates for breeding programs developing CGMMV-resistant varieties.

The use of high-yielding mini and LE cucumber varieties with delayed CGMMV spread, as demonstrated in this trial, is recommended for cultivation in the greenhouses assuming that this would reduce the incidence and spread of CGMMV infection and could reduce economic losses to cucumber growers. However, growers should use efficient sanitization programs between crops, since repeated cultivation of partially resistant cultivars may increase the level of CGMMV particles on various hard surfaces within the greenhouse and render even partial resistance ineffective. Hence there is an urgent need for resistant cultivars with restricted virus movement and replication.

The spread of CGMMV had no specific trends (Supplementary Materials Figure S1), revealing that cultural practices (pruning, de-leafing, lowering, fruit picking) were not the only factors responsible for CGMMV spread. Other factors, such as leachates, chewing insects, bumble bees and contaminated seeds, were possibly playing a role in the spread of CGMMV. In the present study, bumble bees were not used for cucumber plant pollination. However, it is possible that bumble bees moved from an adjacent tomato crop and inadvertently contributed to the CGMMV infection spread between cucumber plants. The contribution of honey bees to the spread of CGMMV infection was previously demonstrated by Darzi et al. [24]. The control of pollinator insects would reduce the incidence and spread of CGMMV infection between cucumber plants.

Our study revealed that grafting did not increase the yields of CGMMV-infected grafted plants between 'Picowell' and 'Bonbon', as compared to the CGMMV infected non-grafted 'Picowell'. However, yield enhancement was successfully achieved using the same scion/rootstock combination in CGMMV disease-free environment. In previous studies, it has been observed that rootstocks can increase or decrease the incidence of non-soilborne virus infections in the scion [32]. In our greenhouse varietal screening, 'Bonbon' was recognized as a tolerant variety. It is possible that the level of resistance of 'Bonbon' to the Canadian CGMMV isolate was not sufficient to confer CGMMV resistance to the scion. It would be interesting to determine if the use of rootstocks with higher level of resistance to CGMMV, such as 'Sepire', 'Bomber' and 'LC13900', would confer virus resistance to the scion. 
The results of present study are in agreement with the previous studies reporting the positive effect of grafting on fruit yield [32,46]. Seong et al. [47] reported $27 \%$ increases in the marketable yield of cucumbers in grafted plants compared to non-grafted scion cultivars. The higher fruit yield and reduced shoot growth of grafted cucumber plants reported in the present study are possibly due to the redirection of assimilates away from vegetative growth toward reproductive organs. Further testing of different scion/rootstock combinations is needed to determine if the use of rootstocks with higher level of resistance to CGMMV will confer virus resistance to the scion without compromising the fruit yield.

Supplementary Materials: The following are available online at http://www.mdpi.com/2073-4395/10/12/1879/s1, Figure S1: Disease progression and spread patterns of Cucumber green mottle mosaic virus (CGMMV) infection in Mini and Long English cucumber varietal trials, based on symptom observation and test confirmation for the CGMMV infection.

Author Contributions: Conceptualization and Funding acquisition, W.E., K.S.L. and W.Z.; Methodology, Investigation and Resources, W.E., V.M. and R.J.H.; Supervision, Formal analysis, Visualization and Writing-Original Draft, W.E.; Reviewing and Editing, W.E., V.M., R.J.H., K.-S.L. and W.Z. All authors have read and agreed to the published version of the manuscript.

Funding: This research was funded by Alberta Crop Industry Development Fund, grant numbers 2014C005R and 2016C007R, and The Business Development and Farm Safety Internal Initiatives through Growing Forward 2, a Canadian Federal-Provincial-Territorial Initiative, grant number 609126.

Acknowledgments: The authors gratefully acknowledge the financial support of the Alberta Crop Industry Development Fund and the Business Development and Farm Safety Internal Initiatives through Growing Forward 2, a Canadian Federal-Provincial-Territorial Initiative. Technical assistance provided by members of the Greenhouse Section at the Crop Diversification Centre South, Brooks, AB is sincerely appreciated. Thanks are also due to Jonathan Griffiths and Antonet Svircev, Agriculture and Agri-Food Canada, Vineland Station, ON for their helpful comments on the manuscript.

Conflicts of Interest: The authors declare no conflict of interest.

\section{References}

1. Dombrovsky, A.; Tran-Nguyen, L.T.T.; Jones, R.A.C. Cucumber green mottle mosaic virus: Rapidly increasing global distribution, etiology, epidemiology, and management. Annu. Rev. Phytopathol. 2017, 55, 231-256. [CrossRef] [PubMed]

2. Mandal, S.; Mandal, B.; Mohd, Q.; Haq, R.; Varma, A. Properties, diagnosis and management of cucumber green mottle mosaic virus. Plant Virus 2008, 2, 25-34.

3. Fletcher, J.T.; George, A.J.; Green, D.E. Cucumber green mottle mosaic virus, its effect on yield and its control in the lea valley, England. Plant Pathol. 1969, 18, 16-22. [CrossRef]

4. Li, J.-X.; Liu, S.-S.; Gu, Q.-S. Transmission efficiency of cucumber green mottle mosaic virus via seeds, soil, pruning and irrigation water. J. Phytopathol. 2016, 164, 300-309. [CrossRef]

5. Liu, H.W.; Luo, L.X.; Li, J.Q.; Liu, P.F.; Chen, X.Y.; Hao, J.J. Pollen and seed transmission of cucumber green mottle mosaic virus in cucumber. Plant Pathol. 2014, 63, 72-77. [CrossRef]

6. Sui, X.; Li, R.; Shamimuzzaman, M.; Wu, Z.; Ling, K.-S. Understanding the transmissibility of cucumber green mottle mosaic virus in watermelon seeds and seed health assays. Plant Dis. 2019, 103, 1126-1131. [CrossRef]

7. Ainsworth, G.C. Mosaic diseases of the cucumber. Ann. Appl. Biol. 1935, 22, 55-67. [CrossRef]

8. Ling, K.-S.; Li, R.; Zhang, W. First report of cucumber green mottle mosaic virus infecting greenhouse cucumber in canada. Plant Dis. 2014, 98, 701. [CrossRef]

9. Tian, T.; Posis, K.; Maroon-Lango, C.J.; Mavrodieva, V.; Haymes, S.; Pitman, T.L.; Falk, B.W. First report of cucumber green mottle mosaic virus on melon in the United States. Plant Dis. 2014, 98, 1163. [CrossRef]

10. Al-Shahwan, I.M.; Abdalla, O.A. A strain of cucumber green mottle mosaic virus (CGMMV) from bottlegourd in Saudi Arabia. J. Phytopathol. 1992, 134, 152-156. [CrossRef]

11. Varveri, C.; Vassilakos, N.; Bem, F. Characterization and detection of cucumber green mottle mosaic virus in Greece. Phytoparasitica 2002, 5, 493-501. [CrossRef]

12. Kim, O.-K.; Mizutani, T.; Natsuaki, K.T.; Lee, K.-W.; Soe, K. First report and the genetic variability of cucumber green mottle mosaic virus occurring on bottle gourd in Myanmar. J. Phytopathol. 2010, 158, 572-575. [CrossRef] 
13. Moradi, Z.; Jafarpour, B. First report of coat protein sequence of cucumber green mottle mosaic virus in cucumber isolated from Khorasan in Iran. Int. J. Virol. 2011, 7, 1-12. [CrossRef]

14. Celix, A.; Luis-Arteaga, M.; Rodriguez-Cerezo, E. First report of cucumber green mottle mosaic tobamovirus infecting greenhouse-grown cucumber in Spain. Plant Dis. 1996, 80, 1303. [CrossRef]

15. Reingold, V.; Lachman, O.; Koren, A.; Dombrovsky, A. First report of cucumber green mottle mosaic virus (CGMMV) symptoms in watermelon used for the discrimination of non-marketable fruits in Israeli commercial fields. New Dis. Rep. 2013, 28, 11. [CrossRef]

16. Zhang, Y.J.; Li, G.F.; Li, M.F. Occurrence of cucumber green mottle mosaic virus on cucurbitaceous plants in china. Plant Dis. 2009, 93, 200. [CrossRef]

17. Budzanivska, I.G.; Rudneva, T.O.; Shevchenko, T.P.; Boubriak, I.; Polischuk, V.P. Investigation of Ukrainian isolates of cucumber green mottle mosaic virus. Arch. Phytopathol. Plant Prot. 2007, 40, 376-380. [CrossRef]

18. Borodynko-Filas, N.; Minicka, J.; Hasiów-Jaroszewska, B. The occurrence of cucumber green mottle mosaic virus infecting greenhouse cucumber in Poland. Plant Dis. 2017, 101, 1336. [CrossRef]

19. Tesoriero, L.A.; Chambers, G.; Srivastava, M.; Smith, S.; Conde, B.; Tran-Nguyen, L.T.T. First report of cucumber green mottle mosaic virus in Australia. Australas. Plant Dis. Notes 2016, 11, 1. [CrossRef]

20. Boubourakas, I.N.; Hatziloukas, E.; Antignus, Y.; Katis, N.I. Etiology of leaf Chlorosis and deterioration of the fruit interior of watermelon plants. J. Phytopathol. 2004, 152, 580-588. [CrossRef]

21. Shargil, D.; Smith, E.; Lachman, O.; Reingold, V.; Darzi, E.; Tam, Y.; Dombrovsky, A. New weed hosts for cucumber green mottle mosaic virus in wild Mediterranean vegetation. Eur. J. Plant Pathol. 2017, 148, 473-480. [CrossRef]

22. Lecoq, H.; Desbiez, C. Viruses of cucurbit crops in the Mediterranean region: An ever-changing picture. In Advances in Virus Research; Loebenstein, G., Lecoq, H., Eds.; Academic Press: Cambridge, MA, USA, 2012; Volume 84, pp. 67-126.

23. Rao, A.L.N.; Varma, A. Transmission studies with cucumber green mottle mosaic virus. J. Phytopathol. 1984, 109, 325-331. [CrossRef]

24. Darzi, E.; Smith, E.; Shargil, D.; Lachman, O.; Ganot, L.; Dombrovsky, A. The honeybee Apis mellifera contributes to cucumber green mottle mosaic virus spread via pollination. Plant Pathol. 2018, 59, $244-251$. [CrossRef]

25. Reingold, V.; Lachman, O.; Belausov, E.; Koren, A.; Mor, N.; Dombrovsky, A. Epidemiological study of cucumber green mottle mosaic virus in greenhouses enables reduction of disease damage in cucurbit production. Ann. Appl. Biol. 2016, 168, 29-40. [CrossRef]

26. Ellouze, W.; Dalpé, S.; Howard, R.J.; Ling, K.-S.; Zhang, W. Managing Cucumber Green Mottle Mosaic Virus in Alberta Greenhouses. Available online: https://open.alberta.ca/dataset/ba4a1311-a775-4f3c9e88-2e6d8d2f27c2/resource/803e64a0-b495-435a-9c3f-0fa70b156aa3/download/256-635-1.pdf (accessed on 15 October 2020).

27. Crespo, O.; Janssen, D.; Robles, C.; Ruiz, L. Resistance to cucumber green mottle mosaic virus in Cucumis sativus. Euphytica 2018, 214, 201. [CrossRef]

28. Pérez-Alfocea, F. Why Should We Investigate Vegetable Grafting? International Society for Horticultural Science (ISHS): Leuven, Belgium, 2015; pp. 21-29.

29. Rouphael, Y.; Kyriacou, M.C.; Colla, G. Vegetable grafting: A toolbox for securing yield stability under multiple stress conditions. Front. Plant Sci. 2018, 8, 2255. [CrossRef]

30. Louws, F.J.; Rivard, C.L.; Kubota, C. Grafting fruiting vegetables to manage soilborne pathogens, foliar pathogens, arthropods and weeds. Sci. Hortic. 2010, 127, 127-146. [CrossRef]

31. Melnyk, C.W. Plant grafting: Insights into tissue regeneration. Regeneration 2016, 4, 3-14. [CrossRef]

32. Davis, A.R.; Perkins-Veazie, P.; Sakata, Y.; López-Galarza, S.; Maroto, J.V.; Lee, S.-G.; Huh, Y.-C.; Sun, Z.; Miguel, A.; King, S.R.; et al. Cucurbit grafting. Crit. Rev. Plant Sci. 2008, 27, 50-74. [CrossRef]

33. Hasama, W.; Morita, S.; Kato, T. Reduction of resistance to corynespora target leaf spot in cucumber grafted on a bloomless rootstock. JPN. J. Phytopathol. 1993, 59, 243-248. [CrossRef]

34. Shibuya, T.; Itagaki, K.; Wang, Y.; Endo, R. Grafting transiently suppresses development of powdery mildew colonies, probably through a quantitative change in water relations of the host cucumber scions during graft healing. Sci. Hortic. 2015, 192, 197-199. [CrossRef] 
35. Sakata, Y.; Sugiyama, M.; Ohara, T.; Morishita, M. Influence of rootstocks on the resistance of grafted cucumber (Cucumis sativus L.) scions to powdery mildew (Podosphaera xanthii U. Braun \& N. Shishkoff). J. Jpn. Soc. Hortic. Sci. 2006, 75, 135-140.

36. Guan, W.; Zhao, X.; Hassell, R.; Thies, J. Defense mechanisms involved in disease resistance of grafted vegetables. HortScience 2012, 47, 164-170. [CrossRef]

37. Gu, J.T.; Fan, S.X.; Zhang, X.C. Effects of rootstocks on the development, disease resistance and quality of Cucumis sativus L. Acta Hortic. 2008, 771, 161-166. [CrossRef]

38. Wang, J.; Zhang, D.; Fang, Q. Studies on antivirus disease mechanism of grafted seedless watermelon. Anhui Nongxueyuan Xuebao 2002, 29, 336-339.

39. Li, R.; Zheng, Y.; Fei, Z.; Ling, K.-S. First complete genome sequence of an emerging cucumber green mottle mosaic virus isolate in North America. Genome Announc. 2015, 3, 3. [CrossRef]

40. Simko, I.; Piepho, H.-P. The area under the disease progress stairs: Calculation, advantage, and application. Anal. Theor. Plant Pathol. 2012, 102, 381-389. [CrossRef]

41. Jeger, M.J.; Viljanen-Rollinson, S.L.H. The use of the area under the disease-progress curve (AUDPC) to assess quantitative disease resistance in crop cultivars. Theor. Appl. Genet. 2001, 102, 32-40. [CrossRef]

42. Hassell, R.L.; Memmott, F.; Liere, D.G. Grafting methods for watermelon production. HortScience 2008, 43, 1677-1679. [CrossRef]

43. Stedman, R.L.; Kravitz, E.; Bell, H. Studies on the efficiencies of disinfectants for use on inanimate objects: III. Physicochemical factors affecting Surface disinfection. Appl. Microbiol. 1955, 3, 71-74. [CrossRef]

44. Stedman, R.L.; Kravitz, E.; Bell, H. Studies on the efficiencies of disinfectants for use on inanimate objects: IV. Factors of importance in practical disinfecting procedures. Appl. Microbiol. 1955, 3, 273-276. [CrossRef] [PubMed]

45. Čech, M.; Branišová, H. Nonrelatedness between symptoms and cucumber virus 4 content in different cucumber cultivars. Biol. Plant. 1976, 18, 58-62. [CrossRef]

46. Usanmaz, S.; Abak, K. Plant growth and yield of cucumber plants grafted on different commercial and local rootstocks grown under salinity stress. Saudi J. Biol. Sci. 2019, 26, 1134-1139. [CrossRef] [PubMed]

47. Seong, K.C.; Moon, J.H.; Lee, S.G.; Kang, Y.G.; Kim, K.Y.; Seo, H.D. Growth, lateral shoot development, and fruit yield of white-spined cucumber (Cucumis sativus cv. Baekseong-3) as affected by grafting methods. J. Korean Soc. Hortic. Sci. 2003, 44, 478-482.

Publisher's Note: MDPI stays neutral with regard to jurisdictional claims in published maps and institutional affiliations.

(C) 2020 by the authors. Licensee MDPI, Basel, Switzerland. This article is an open access article distributed under the terms and conditions of the Creative Commons Attribution (CC BY) license (http://creativecommons.org/licenses/by/4.0/). 